\title{
Urgences
}

\section{il y a...}

\section{Célyne Fortin}

Numéro 15, octobre 1986

Épigraphiques

URI : https://id.erudit.org/iderudit/025342ar

DOI : https://doi.org/10.7202/025342ar

Aller au sommaire du numéro

\section{Éditeur(s)}

Urgences

\section{ISSN}

0226-9554 (imprimé)

1927-3924 (numérique)

Découvrir la revue

Citer ce document

Fortin, C. (1986). il y a... Urgences, (15), 82-82. https://doi.org/10.7202/025342ar

Ce document est protégé par la loi sur le droit d'auteur. L'utilisation des services d’Érudit (y compris la reproduction) est assujettie à sa politique d'utilisation que vous pouvez consulter en ligne.

https://apropos.erudit.org/fr/usagers/politique-dutilisation/ 


\section{Célyne Fortin}

Il $y$ a toujours au matin

un homme

que regarde la mer.

Hélène Sansalone: "Jeune homme dans un paysage marin" dans L'oeil versatile, (dans Levée d'encre, no 1, Paris-Montréal)

il y a

des soirs où passent à la télé

des visages d'hommes de guerre

j'en ai vu un qui

toujours

par son regard et la hantise

qui le remplissait

me poursuivra

tel une obsession

jusque loin

tard

au matin

avait dans ses yeux

tout un océan de métal

en même temps

tout un ciel avec des ailes

des oiseaux

peut-être

que regarde

au même moment

sa femme ou

la mer 